\title{
AID AND THE DUTCH-DISEASE IN ETHIOPIA ${ }^{1}$
}

\author{
Teferi Mequaninte Tensay ${ }^{2}$
}

\begin{abstract}
The paper analyses the "Dutch Disease" effect of foreign aid on the Ethiopian Economy. After a brief review of aid theory, it goes on reviewing the available evidences about the Dutch disease effects aid has in the other countries. Then illustrative model is presented. The study employed three stage-least square methods in estimating the real exchange rate and aid variable, on the one hand, and export performance and aid, on the other. The finding is that external aid inflows to Ethiopia result in appreciation of exchange rate and hence loss of export competitiveness, that is, "Dutch Disease" problem has been identified. The study concludes that for external aid inflows to be an effective investment, economic policy needs to focus infrastructure development and the government needs to subsidize firms in the tradable sector.
\end{abstract}

\footnotetext{
${ }^{1}$ The final version of this article was submitted in October 2008.

${ }^{2}$ Economic Research and Monetary Policy Directorate National Bank of Ethiopia, E-mail: tefmeq@yahoo.com
} 


\section{Introduction}

Following the introduction of the Structural adjustment program (SAP) in 1992 to the Ethiopian economy, there was a massive inflow of foreign aid in the form of grants, concessional loans and technical assistance. Net aid ${ }^{3}$ inflows to Ethiopia during the Derg period were around 7 percent of GDP and are doubled to 14 percent of GDP during the EPRDF regime. These elevated flows have raised a number of concerns, ranging from fears about the effect of aid inflows on the real exchange rate and export performance. The source of anxiety for all this is the Dutch disease problem of foreign aid. While seemingly beneficial foreign aid inflows may generate undesirable effects in the economy. These undesirable effects include a decline in export performance and manufacturing production caused by appreciation of the real exchange rate and resources moving out of manufacturing into other sectors (Timothy, 1997). There are also concerns about aid sustainability. Specifically, while LDCs have been forced to take on greater burden of global adjustment, most donor countries have been unwilling to expand financial support for adjustment in the LDCs (Bigsten, 2003). These could be due to different motives by the donor countries. Instead of addressing the most developmental constraints of a recipient country, donors may wish to enhance the military prow ness of a recipient country, to promote their commercial interest, to support a friendly government in power, and/or to acquire goodwill in the expectation that it would be politically valuable later (Krueger, 1993). As has been well documented in the works of Adams et al (1994), foreign aid inflows cannot continue indefinitely given donor fatigue and the growing competition for aid funds among LDCs.

Still, there are concerns about the absorptive capacity of the recipient economy, and particularly of the government itself. The impact of aid is rather complex, since there are direct effects of aid disbursement as well as indirect effect on the spending patterns of the public sector of the recipient country and on government policy. The government may use aid to escape the burdens of their foolish economic policy. (Mosley et al, 1992). The more general concern of Dutch disease is that whether external aid inflows have been temporary or permanent and weather they were spent on imports or domestically produced goods and services.

The principal economic rationale for aid is to increase growth rates in recipient countries, usually measured by its impact on real exchange rate. Yet, after decades of capital transfer to Ethiopia, the effectiveness of achieving this objective remains

\footnotetext{
${ }^{3}$ Aid according to the OECD definition is both grant and a loan with grant element of 25 percent or above.
} 
questionable as conformed by numerous studies of the empirical relationship between aid and growth. In an effort to boost Ethiopia's economic growth the real exchange rate and its interplay with external aid inflows have been crucial for purposes of strategic economic decision making and efficient policy management.

This paper attempts to develop an empirical model for the real exchange rate impact of foreign aid in Ethiopia. The paper then links this with an export performance model in order to identify policy implications and recommendation. Generally it is hypothesized, first, that whether external aid inflows to Ethiopia results in real exchange rate appreciation or depreciation is an empirical question, and second, that exports respond positively to a good policy management of foreign aid.

This paper has five sections. Following this introductory section, part two presents a review of the existing literature regarding pro-aid and contra-aid arguments. Section three is devoted to the discussion of model specification, data sources and methodology. The model specification is based on the Dutch disease model as reviewed in section two. Also in this section are, empirical result and interpretation of the coefficients. The last part summarizes the paper and provides conclusions and policy implications.

\section{Literature survey}

There is a substantial amount of literature on the macroeconomics of aid. The pro-aid argument focuses on the complementarity of aid to growth. Prolific writers like Griffin, Todarro and Chenery and Strout are in this group. The major themes covered in the pro-aid argument include the two-gap model; aid and growth; aid, investment and imports; and the saving debate.

The two-gap model was developed by Bruno and Chenery (1962) and then elaborated further in Chenery and Strout (1966). This model had three potentially binding constraints on growth: a saving constraint (which might limit investment), a foreign exchange constraint (which might limit investment because of the high import content of investment), and an absorption constraint (which set an upper limit for the rate of growth).

Griffin (1970) and Todarro (1989), for instance, stressed that whenever there is a foreign exchange gap as well as the saving gap, growth would be impaired unless that gap is filled by foreign aid. Development economists such as Rosenstient Rodan (1961), as cited in Hansen et al 2000, also assumed that each dollar of foreign 
resources in the form of aid would result in an increase of one dollar in total savings and investment. It is based on this belief that donors like European Economic Commission EEC and World Bank provide official development Assistance (ODA) to the Less Developed countries (see EEC, 1990; World Bank, 1994). Similarly, Chenery and Strout (1966) argued that aid's impact on growth is as a supplement to scarce domestic resource. Clark (1991) has also over emphasized the importance of foreign aid by saying that "foreign aid can be used on the immediate relief of poverty, infrastructure, and institutional building or on promoting agriculture and capital investment".

The two-gap model has been subject to a number of general criticisms and some directed more specifically at its application to analyzing aid's impact on the economy. Findlay (1971) was the first to criticize application of the two-gap model and Edwards and Van Wijnbergen (1989) heightened the attack on the ground that it ignores relative prices, and thus turns the focus towards the real exchange rate as a crucial variable influencing the effectiveness of foreign aid (Dutch disease theory).

Unlike the "two-gap" literature, the modern view of developmental aid theory focuses on both resource accumulation and improving the efficiency of resource use (Krueger O. 1985). In the new macroeconomics of aid, authors like Loxley (1998) point to the quality of assistance and direction of aid. Griffin (1970) underlined that if aid to developing countries displaces their saving rate or raises its capital out put ratios $(x / k)$ to a sufficient extent, then it is just possible that aid may immiserise the recipient countries. Morrisey (1992) has argued that the link between aid and growth is in direct and that aid affects the real exchange rate, which in- turn may constrain any beneficial impact on the growth rate. Similarly Edwards and Van Wijnbergen (1989), Vos (1989), and Younger (1992), have focused on aid as causing Dutch disease.

Historically, the term "Dutch disease" was first used to reflect the decline in the Netherlands' export competitiveness following the discovery of the Groningen gas field in the early 1970s (Benjamin et al., 1989). Dutch disease refers to the coexistence within the traded goods sector of progressing and declining or booming and lagging sub-sectors (Corden and Neary, 1982). A boom is one of the traded goods sectors (due to for instance foreign aid) raises the marginal product of the mobile factors employed in that sector. Higher factor returns in the booming sector will draw mobile factors away from the other sectors and into the booming sector (resource movement effect). The non-booming sector will thus contract. The higher real incomes resulting from the boom leads to extra spending on the non-tradable, which raises their price (spending effect). The spending effect will, in turn, causes the real exchange rate to appreciate and hence a loss of export competitiveness in the 
international market. Most studies of Dutch disease literature since then have been used to analyze the problems associated with managing revenue from the booming sector of the economy.

From a structural adjustment and macroeconomics perspective, Edwards and Van Wijnbergen (1989) have stressed the similarity between increased income from natural resource and aid inflows by indicating that firstly both come in the form of additional foreign exchange, secondly the impact of both is temporary and third when spent on non-traded goods put upward pressure on the real exchange rate.

Van Wijnbergen (1986) using the Dutch-disease model to analyze the effect of foreign aid in Africa, arrived at the conclusion that, by partially spending on nontraded goods, increase in real volume of aid places upward pressure on the real exchange rate. Yet Ogun (1995) found that capital inflow to Ghana caused the real exchange rate to depreciate. Similarly, in their study of foreign aid and the Dutch disease in Tanzania, Adams et al. (1994) found that the aid inflows to Tanzania were buying economic reforms and policy changes that were pro-tradable and dampened the potential for the aid induced real appreciation. The stabilization program initiated by New Zealand in 1984 led to high interest rates, an inflow of foreign capital, and the appreciation of their exchange rate. Although trade liberalization initially resulted in depreciation of the real exchange rate in Chile, the real exchange rate began appreciating between 1979 and 1982 as a result of capital inflows and wage indexation (Schiff and Valdes, 1998).

\section{Model specification and estimation}

\subsection{Model specification}

The impact of external aid inflows on the real exchange rate (RER) is estimated using the model of real exchange rate developed by Edwards (1989). In the modern theory the real exchange rate, $(R E R)$ is defined as the domestic relative price of tradable goods $\left(P_{T}\right)$ to non-tradable goods $\left({ }_{N T}\right)$, that is, $R E R=\left(e P_{T}, P_{N T}\right)$ compatible with the attainment of internal and external equilibrium.

Internal equilibrium presupposes that the market for non-tradable clears in the current period and is expected to be so in the future and it is attained when the supply and demand for non-tradable goods are equal (Montiel 1996, cited by Baffes et al, 1999).

$Y_{N}(R E R)=(1-\alpha) R E R C+G_{N}, \quad \partial Y_{N} / \partial R E R<0$ 
Where,

$Y_{N}$ is the production of non-traded goods,

$G_{N}$ is government consumption of non traded goods,

$\alpha$ is the share of traded goods in total consumption, and

$C$ is total private consumption measured in traded goods

$e$ is the nominal exchange rate

External equilibrium (trade balance) implies that the current account balances both in the current and future periods are compatible with long-run sustainable capital flows (Elbadawi, 1994). Thus, using Montiel (1996, as cited by Baffes et al, 1999) equations below, the hypothesized relationships can be specified.

$$
f=Y_{T}(R E R)-G_{T}-\alpha C+A-r f
$$

Where,

$f$ is net foreign assets, and $f$ is change in net foreign assets over time,

$Y_{T}(R E R)$ is the domestic supply of traded goods,

$G_{T}$ is government spending on traded goods

$A$ is net aid inflows and $r f$ is external debt services.

The intersection of internal and external balance (Equation 1 and 2) produces the equilibrium real exchange rate. At such an intersection, both the internal and external balance are achieved. Setting the right hand side of Equation 2 to zero, and combining this with Equation 1 gives;

$R E R^{*}=R E R^{*}\left(G_{N}, G_{T}, A, r_{w}\right)$

Where, $r_{w}$ is the world interest rate.

The above derivation is for illustrative purposes and it serves us to show how the fundamentals (government consumption, Terms of trade, Capital formation, and technological progress) influence the movement of the real exchange rate. For practical application it is possible to extend the model in many ways. For example, Baffes et al (1999) discuss extension of the model involving rationing of foreign credit, change in the domestic relative price of traded goods, and short run rigidities in the domestic wages and prices. In the case of Ethiopia important extensions like Terms of Trade, trade policy and foreign reserve can be made. Incorporating all the 
fundamentals and short run macroeconomic policy variables, the model for the real exchange rate that is used for estimation can be formulated as:

$\operatorname{LogRER}=\beta_{0}+\beta_{1} \log (T O T)_{t}+\beta_{2} \log (A I D)_{t}+\beta_{3} \log (G C N)_{t}+\beta_{4} \log (C P S)_{t}+{ }_{5} \log \left(G R G D P_{t}+\right.$ $\beta_{5} \log \left(G R G D P_{t}+\beta_{6} \log \left(I N V G D P+\lambda \log (C B R)_{t}+\alpha\left(\log N E R_{t}-\log N E R_{-1}\right)+U_{t}\right.\right.$

NER stands for nominal devaluation and $U_{t}$ for the error term.

Where

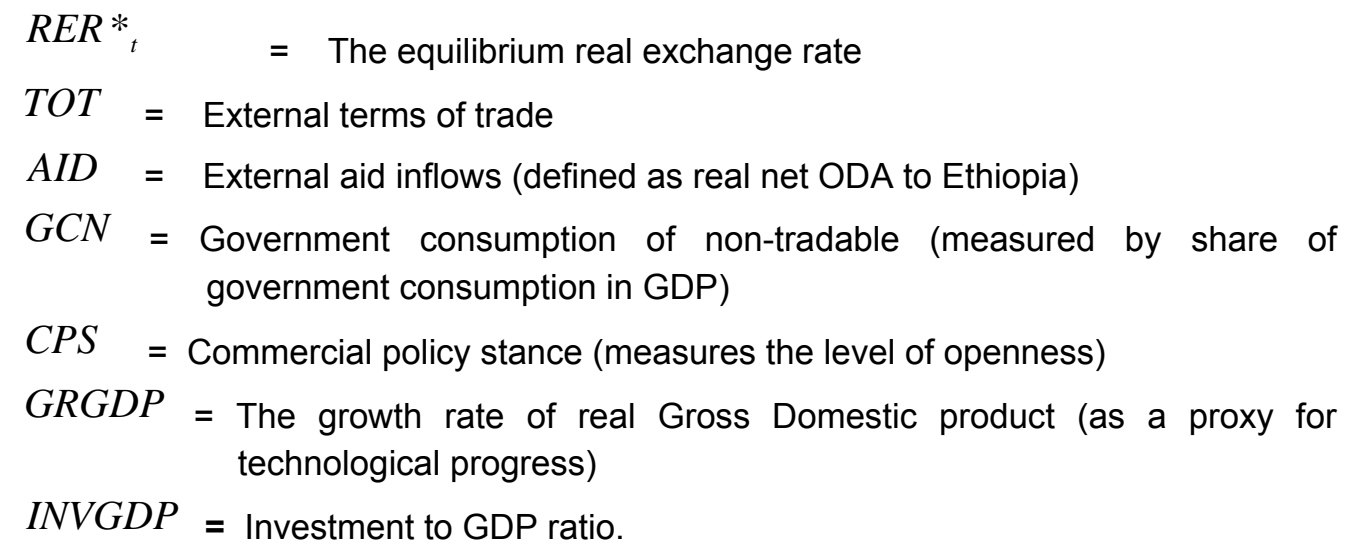

The expected theoretical impacts of the respective fundamentals are as follows:

TOT (?) - Its impact on the RER depends on the relative strengths of the direct income effect operating through the demand for non-tradables and the indirect substitution effects that operate through the supply of non-tradables. If the income effect associated with deterioration is stronger than the Substitution effect, a depreciation of the RER will occur. In Elbadawi and Soto's (1997) study of seven developing countries, in three case, an improvement in the term of trade appreciated the real exchange rate, while in four cases, an improvement in the terms of trade depreciated the real exchange rate.

AID (-) - By increasing real incomes and consequently the demand for both traded and non-traded goods, it tends to cause the RER to appreciate. In his study of twelve developing countries, Edwards (1989) found that an increase in capital inflows appreciated the real exchange rate, as expected. 
GCN (?) - Increases in government expenditure on non-tradable appreciates the RER, while those on tradable causes the RER to depreciate. Edwards (1989) found that an increase in government consumption appreciated the real exchange rate in four of the equations he estimated for a group of twelve developing countries, while in the other two equations, an increase in government consumption depreciated the real exchange rate.

CPS (+) - Decreases in the parallel (or black) market premium tend towards RER depreciation. In their study of Cote d'Ivoire and Burkina Faso, Baffes et al (1999) found results consistent with the theory; reforms that are aimed at liberalizing trade are consistent with a depreciated real exchange rate.

GRGDP (?) - Technological progress appreciates the RER if gains emanating from productivity enhancement in the tradable Sector override those in the nontradable sector. Edwards (1989) found that an increase in technological progress depreciated the real exchange rate in all his regressions. Aron et al (1997), on the other hand, found that an increase in technological progress appreciated South Africa's real exchange rate.

CBR (?) - Central Bank reserve intervention indicates the capacity of the Bank to defend the currency (Aron et al, 1997). An increase in reserve has the effect of appreciating the real exchange rate, while a decrease in reserves depreciates the real exchange rate. In their study of the determinants of the real exchange rate for South Africa, Aron et al (1997) found results consistent with the theory; an increase in reserves appreciated the real exchange rate.

$N E R_{t}(+)$ - Nominal devaluation tends to depreciate the RER.

INVGDP (?) - Its impact on the real exchange rate depends on whether an increase in investment changes the composition of spending on traded and nontraded goods. If an increase in the share of investment in GDP changes the composition of spending towards traded goods, it will lead to a depreciation in the real exchange rate (Baffes et al; Edwards, 1989). On the other hand, a change towards non-traded goods appreciates the real exchange rate. For example, Baffes et al (1999) found that an increase in the share of investment in GDP depreciated the real exchange rate in Cote d'Ivoire. Edwards (1989) also found that increases in the share 
of investment in GDP resulted in depreciation in the real exchange rate in his study of twelve developing countries.

Following the definition of the real exchange rate, a negative sign (i.e., -) represents an appreciation of the real exchange rate.

In estimating the relationship between export performance and real exchange rate, an expanded export performance model adopted from Vos (1993) is used. In this model, growth of real exports (EXP) is assumed to be a function of (change in) relative prices (i.e., RER), income or rate of output growth of the trading partners (YTP), real exchange misalignment (REMIS), and external aid inflows (AID). Thus export model to be estimated is:

$$
\operatorname{LogEXP}=f[\log R E R, \log Y T P, R E M I S, \log A I D]
$$

The expected theoretical impacts are:

$R E R \quad(+) \quad$ - Increases in the real exchange rate are expected to result in exports expansion.

YTP (+) - Output growth of trading partners is envisaged to have a positive effect on Ethiopia's exports.

REMIS (-) - Real exchange rate misalignment, measured by the deviation of the actual real exchange rate from its long run equilibrium level, has a disincentive effect on exports and is thus likely to reduce export growth.

AID (?) - A good or bad aid dispersement policy (proxied by real net ODA to Ethiopia) tends to elicit positive or negative response from the export sector.

The export model (Equation 5) shows a linkage with the real exchange rate model through the real exchange rate and aid variables. In addition to the RER effect in the export model, the aid variable permits the analysis of foreign aid on exports. Thus we have the indirect effect of aid on exports through the RER and the direct linear effect of aid. 


\subsection{Estimation of the model}

In estimating the empirical relationship between the real exchange rate and external aid inflows on the one hand and the aid variable and export performance model on the other, the study employed three-stage least square methods. The source of the data were National Bank of Ethiopia (NBE), IFS-CDROM and OECD website. The data used is annual, covering the period 1970 to 2003. Given the fact that a substantial amount of government consumption contains foreign aid and that there is no disaggregated data for the government consumption of non-tradable, GCN is excluded from the empirical estimation. Similarly, since technological progress can be captured by investment to GDP ratio (see Jing Xu, 2003) and our economy is mainly agrarian, GRGDP has been also excluded from the empirical model.

The results of the three-stage least square estimation for the real exchange rate is provided in Equation 6 below. Figures in parenthesis under the equation represent t-values.

$$
\begin{aligned}
& \log R E R=6.265-0.157 * \log (T O T)-0.437 * \log (A I D)+0.918 \log (C P S)- \\
& \text { (t-value) (6.19) (0.89) (-3.49) } \\
& 0.366 \log (I N V G D P)+0.181 \log (C B R)+0.734 \log (N E R) \\
& (-1.62)
\end{aligned}
$$

Adjusted $\mathrm{R}^{2}=0.66$

DW statistic $=1.48$

As one can see from the results, taken together, the fundamentals explain $66 \%$ of the variations in the real exchange rate. The positive parameters on commercial policy stance and central Bank reserve imply a tendency towards real exchange rate depreciation. However, aid variable exhibit negative coefficient and, therefore, tend to appreciate the real exchange rate. Variables found to be insignificant are: terms of trade, investment to GDP ratio and nominal exchange rate. Generally all significant variables, that is, commercial policy stance, central bank reserve and aid captured in the estimation bear the expected theoretical signs.

The major interest of this study is the impact of external aid inflows on the real exchange rate in Ethiopia. Consistent with the conventional "Dutch disease" effect of aid on the real exchange rate as postulated in theoretical real exchange rate model, Ethiopia's experience exhibits a negative impact of on the real exchange rate. In 
other words, aid inflows lead to real exchange rate appreciations and hence the existence of Dutch disease problem of aid in Ethiopia. The appreciation impact of aid on the real exchange rate can be explained by the fact that aid inflows instead of being directly invested in the tradable sectors of agriculture and industry, is likely be invested in the non-tradable service sectors like public administration and defense, transport and construction and recurrent expenditures in general. Hence, the spending effect of aid inflows to the Ethiopian economy is likely to cause price increases in this sector that will invariably spill over to the other sectors as well. It is no surprising that the government is grappling with inflation. With the service sector being low on the extent of tradability, such inflationary tendencies have had a potential appreciation effect on the real exchange rate.

The results of the three-stage list square estimation on export performance model, as indicated in the Equation 7 below, revels the following. All figures in parenthesis under the equation represent $t$-values and probabilities respectively.

$$
\begin{aligned}
& \log E X P=1.739+0.531 \log (R E R)+0.684 \log (Y T P)-1.021 \log (R E M I S)+0.225 \log (A I D) \quad(7) \\
& t \text {-value }) \quad(1.12)
\end{aligned}
$$

Adjusted $\mathrm{R}^{2}=0.89$

DW statistic $=1.50$

All together, $89 \%$ of the export performance model is explained by the explanatory variables. As expected, increases in out put or income of Ethiopia's trading partners positively affected the performance of exports. Changes in the real exchange rate variable also bear the expected positive sign but is insignificant. Generally, depreciations in the real exchange rate positively affect export performance. The negative coefficient on the real exchange rate misalignment term highlights the adverse effect it has on export performance. For the policy environment proxy (i.e., aid), an insignificant relationship is seen to exist. This suggests that for aid to have a significant positive impact on export performance, production subsidies to firms in the tradable sector, or simply export subsidies are required. The government could consider export promotion in the form of both price and non-price incentives. Alternatively, the government could try interest subsidies, that is, the introduction of a subsidy to banks to make it possible for them to charge lower interest rates for exporting firms. For this to be effective, however, donors should delegate more responsibility to the Ethiopian government, while at the same time creating an incentive structure for good performance. This would include among other things a shift towards ex post conditionality and aid allocation according to performance. 


\section{Conclusion and policy implications}

The Ethiopian economy has been the recipient of substantial aid inflows for its development activities, and these inflows have been increased in recent years. Give donor fatigue and the growing competition for aid funds among less developed countries, any current curtailment of these inflows could have adverse effects on the Ethiopian economy. One implication for macroeconomic management is that rather than using aid for current consumption it is vital to use it in infrastructure developments like education, health services, road networks in the peripheral areas etc. In a situation with poor administrative capacity and a large debt burden, it would also make sense to shift aid resources to debt service and Balance of payments (or budget) support. This will make it possible for the Ethiopian government to use more of its own resources for development, at the same time as reduced debt should stimulate private investment. This will further pave the way for curtailment of aid dependence in the future. Global trends show that there is a tendency towards reduced aid flows from the donor community. For developing economies like Ethiopia, this trend has serious implications for the country's development activities. In order to prevent the economy against future losses, in the form of debt servicing for instance, it is appropriate to adopt strategies for reducing aid intensity and hence dependence by continuously improving the institutional mechanisms of aid delivery. This requires effective civil service reform, transparency, democratization and good governance.

The paper tried to develop an empirical model for the Dutch disease effect of foreign aid on the Ethiopian economy. The analysis emerges from the discussion of the 'spending effect' within a classic Dutch disease framework. By employing the threestage estimation techniques, the study concludes that aid inflows lead to real exchange rate appreciation in the case of Ethiopia and hence the loss of export competitiveness in the international market. This calls for a sound policy environment so as to elicit good macroeconomic performance. Policy management thus needs to focus on ensuring the prevalence of sound macroeconomic fundamentals such as small black market premium, spending on infrastructure, openness to trade, providing credit to firms in the tradable sector, good governance and other policy measures. Ensuring of a sound macroeconomic management is a pre condition for aid eligibility in the face of donors. This implies that with a good policy environment, external aid could be an effective investment in the Ethiopian economy and could spur the realization of the country's poverty reduction strategy. 


\section{References}

Adams Chris, Arne Bigsten, Paul Collier, Eva Julin, and Steve O'Connell. 1994. Evaluation of Swedish Development Co-Operation with Tanzania: A Report for the Secretariat for Analysis of Swedish Development Assistance, Ministry for Foreign Affairs, Stockholm.

Adams, C. 1992. Recent Developments in Economic Methods: An Application to Kenya, African Research Consortium (AERC), Special Paper No. 15, Nairobi.

Arne Bigsten. 2003. Can Aid Generate Growth in Africa? Working Papers in Economics No 3, Goteborg University.

Aron Janine and Elbadawi Ibrahim A. 1992. Parallel Market, the Foreign Exchange Auction, and Exchange Rate Unification in Zambia. Policy Research Working Paper WPS 909, the World Bank.

Aron Janine, Elbadawi Ibrahim A. and Kahn Brian. 1997. Determinants of the Real Exchange Rate in South Africa, Center for the Study of African Economies, WPS 97, CSAE Publishing, Oxford.

Baffes John, Elbadawi Ibrahim A. and O'Connell Stphen A. 1999. Single-Equation Estimation of the Equilibrium Real Exchange Rate. In Hinkle Lawrence E. and Montiel Peter J. (ed.).

Beatrice Kalinda M. 2001. Long-run Determinants of the Real Exchange Rate in Zambia. Department of Economics, Goteborg University.

Benjamin, N. C., S. Devarajan, and R. J. Weiner. 1989. The Dutch Disease in Developing Country: Oil Reserves in Cameroon. Journal of Development Economics, Vol. 81.

Bruno, N. and Chenery, H. B. 1962. Development Alternatives in an Open Economy: The Case of Israel, Economic Journal Vol. 77, No. 285.

Chenery, H. and A. Strout. 1966. Foreign Assistance and Economic Development, American Economic Review, Vol. 56.

Clark, D. P. 1991. Trade Versus Aid: Distributions of Third World Development Assistance Economic Development and Cultural Change, Vol. 39, No. 4.

Corden W. M. and J. P. Neary. 1982. Booming Sector and De-industrialization in Small Open Economy. The Economic Journal.

Edwards, S. and S. Van Wijnbergen. 1989. Disequilibrium and Structural Adjustment. Handbook of Development Economics, Vol. 2, Amsterdam: North Holland.

EEC. 1990. Ethiopia and the European Community, Brussels.

Elbadawi, Ibrahim A. 1994. Estimating Long-Run Equilibrium Real Exchange Rate. In John Williamson, E. D., Washington D.C, Institute for International Economics Elbadawi Ibrahim A and Soto Raimundo. 1997. Real Exchange Rates and Macroeconomic Adjustment in Sub-Saharan Africa and Other Developing Countries. Journal of African Economies, No. 6 Vol. 3.

Findlay, Rodan. 1971. The Foreign Exchange Gap and Growth in Developing Countries, in J. Bhagwati et al. (eds.), Trade, Balance of Payments, and Growth, North Holland, Amsterdam.

Griffin, K. 1970. Foreign Capital, Domestic Savings and Economic Development. Oxford Bulletin of Economics and Statistics, Vol. 18.

Hansen, H. and F. Tarp. 2000. Aid Effectiveness Disputed. Journal of International Development 12. 
Jing Xu. 2003. Real Exchange Rate Misalignment in Developing Countries: Empirical Investigations. Economics $423 \mathrm{P}$. Mueser.

Krueger, Anne O. 1993. Political Economy of Policy Reform in Developing Countries. Cambridge: MIT Press. 1985. Some Aspects of Capital Flows to Developing Countries

Lancaster, C. and S. Wangwe. 1998. What is Aid Dependence. Workshop Paper, AERC Collaborative Project on the Transition from Aid Dependence. Nairobi.

Loxley, J. 1998. Interdependence, Disequilibrium and Growth Reflections on the Political Economy of North-South Relations at the Turn of the Century. International Economy Series, IDRC Canada.

Maurice Schiff and Alberto Valdes. 1998. Agriculture and the Macro-economy. Policy Research Working Paper 1967, World Bank.

Morrisey, O. 1992. The Mixing of Aid and Trade Policies. Credit Research Paper No. 92/5. Nottingham: Center for Research in Economic Development and International Trade.

Mosley, P., Hudson, J. and Horrell S. 1992. Aid, the Public Sector and the Market in Less Developed Countries: A Return to the Scene of the Crime. Journal of International Development 4(2).

1987. Aid, the Public Sector and the Market in Less Developed Countries, Economic Journal 97, No. 2.

Ogun, O. 1995. Real Exchange Rate Movements and Export Growth: Nigeria, 1960-1990. Research Paper 82, Nairobi: African Economic Research Consortium.

Rosenstein-Rodan, P. 1961. International Aid for Underdeveloped Countries. Review of Economics and Statistics 43

Timothy S. Nyoni. 1997. Foreign Aid and Economic Performance in Tanzania. African Economic Research Consortium, Research paper 61, Nairobi.

Todarro, Michael P. 1989. Foreign Investment and Aid: Old Controversies and New Opportunities. In Economic Development in the Third World, New York.

Van Wijnbergen, S. 1986. Macroeconomic Aspects of the Effectiveness of Foreign Aid: on the Two-gap Model, Home Goods and Disequilibrium and Real Exchange Rate Misalignment. Journal of International Economics, No. 21.

1985. Aid Export Promotion and the Real Exchange Rate: An African Dilemma?. World Bank Country Policy Department Discussion Paper, No 54. Washington D.C.: The World Bank.

Vos, R. 1993. The Analytics of the Semi-industrialized Economy. The Hague: Institute of Social Studies.

Vos R. 1989. Ecuador: Windfall Gains, Unbalanced Growth and Stabilization. In E.V.K Fitzgerald and R. Vos, eds.; Financing Economic Development: A Structural Approach to Monetary Policy. Aldershot Growth Publishers.

White, H. 1992. The Macro-economic Impact of Development Aid, a Critical Survey. Journal of Development Studies. Vol. 28, No. 2 (January).

World Bank. 1994. Adjustment in Africa: Reforms, Results, and the Road Ahead, a World Bank Policy Research Report, Oxford University Press.

Younger, S. D. 1992. Aid and Dutch Disease: Macroeconomic Management When Everybody Loves You. World Development. Vol. 20, No. 12. 


\section{Annex}

System: FINALSYSTEM

Estimation Method: Iterative Three-Stage Least Squares

Date: 05/13/05 Time: 17:19

Sample: 19702001

Included observations: 32

Total system (unbalanced) observations 63

Instruments: CBR INVGDP TOT ODA YTP CPS REMIS NEER C

Convergence achieved after: 6 weight matricies, 7 total coef. iterations

\begin{tabular}{rrrrr}
\hline \hline & Coefficient & Std. Error & t-Statistic & Prob. \\
\hline \hline $\mathrm{C}(1)$ & 6.262044 & 1.010992 & 6.193959 & 0.0000 \\
$\mathrm{C}(2)$ & 0.918235 & 0.175861 & 5.221382 & 0.0000 \\
$\mathrm{C}(4)$ & -0.437671 & 0.125174 & -3.496511 & 0.0010 \\
$\mathrm{C}(6)$ & 0.734067 & 0.504283 & 1.455666 & 0.1516 \\
$\mathrm{C}(7)$ & 0.181899 & 0.053918 & 3.373645 & 0.0014 \\
$\mathrm{C}(3)$ & -0.157174 & 0.175684 & -0.894644 & 0.3752 \\
$\mathrm{C}(13)$ & -0.366198 & 0.225652 & -1.622841 & 0.1108 \\
$\mathrm{C}(8)$ & 1.739559 & 1.552079 & 1.120793 & 0.2676 \\
$\mathrm{C}(9)$ & 0.225960 & 0.193693 & 1.166590 & 0.2488 \\
$\mathrm{C}(10)$ & 0.531618 & 0.268414 & 1.980587 & 0.0530 \\
$\mathrm{C}(11)$ & 0.684035 & 0.171202 & 3.995479 & 0.0002 \\
$\mathrm{C}(12)$ & -1.020597 & 0.215283 & -4.740727 & 0.0000 \\
\hline \hline
\end{tabular}

Determinant residual covariance

0.002023

Equation: $\operatorname{LOG}($ REER $)=\mathrm{C}(1)+\mathrm{C}(2)^{*} \mathrm{LOG}(\mathrm{CPS})+\mathrm{C}(4)^{*} \mathrm{LOG}(\mathrm{ODA})+$

$\mathrm{C}(6)^{*}(\mathrm{LOG}(\mathrm{NEER})-\mathrm{LOG}(\mathrm{NEER}(-1)))+\mathrm{C}(7)^{*} \mathrm{LOG}(\mathrm{CBR})+\mathrm{C}(3)$

*LOG(TOT)+C(13)*LOG(INVGDP)

Observations: 31

\begin{tabular}{|c|c|c|c|}
\hline R-squared & 0.734607 & Mean dependent var & 4.419524 \\
\hline Adjusted R-squared & 0.668258 & S.D. dependent var & 0.368057 \\
\hline S.E. of regression & 0.211990 & Sum squared resid & 1.078553 \\
\hline Durbin-Watson stat & 1.487043 & & \\
\hline \multicolumn{4}{|c|}{$\begin{array}{c}\text { Equation: } L O G(R E P)=C(8)+C(9)^{*} L O G(O D A)+C(10)^{*} \text { LOG(REER) + } \\
C(11)^{*} \text { LOG }(Y T P)+C(12)^{*} L O G(R E M I S)\end{array}$} \\
\hline \multicolumn{4}{|c|}{ Observations: 32} \\
\hline R-squared & 0.910814 & Mean dependent var & 7.361908 \\
\hline Adjusted R-squared & 0.897602 & S.D. dependent var & 0.821014 \\
\hline S.E. of regression & 0.262722 & Sum squared resid & 1.863619 \\
\hline Durbin-Watson stat & 1.502982 & & \\
\hline
\end{tabular}

Annex: Estimated Result 